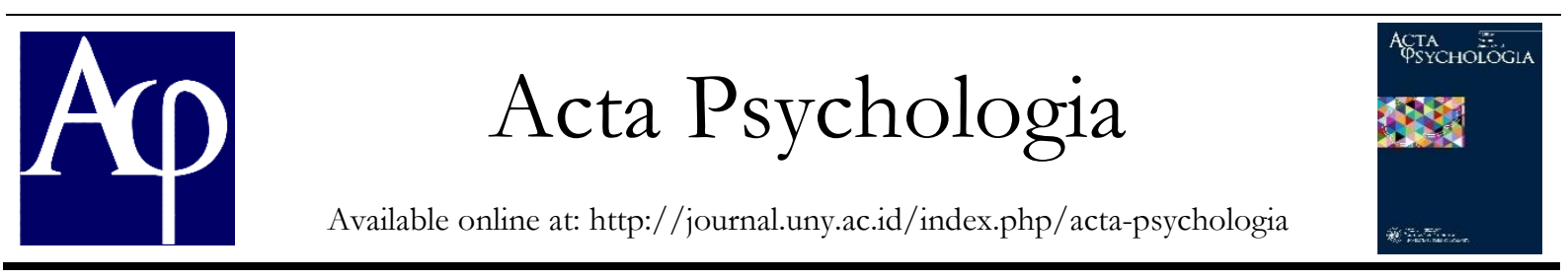

\title{
Pengaruh Beban Kerja terhadap Stres Kerja pada Guru Tahfidz di Pesantren Terpadu Darul Qur'an Mulia
}

\author{
Tåkiatun Nafs \\ Program Studi Psikologi, Universitas Negeri Yogyakarta; Jl. Colombo No. 1 Sleman Yogyakarta, \\ 55281 \\ tazkia.98@gmail.com
}

\begin{abstract}
Abstrak
Penelitian ini bertujuan mengetahui pengaruh beban kerja terhadap stres kerja pada Guru Tahfidz di Pesantren Terpadu Darul Qur'an Mulia. Beban kerja bersifat multidimensi yang terbagi menjadi 3 dimensi, yaitu: beban waktu, beban upaya mental, dan beban tekanan psikologis. Penelitian ini akan meneliti pengaruh setiap dimensi secara bersama-sama terhadap stres kerja pada Guru Tahfidz di Pesantren Terpadu Darul Qur'an Mulia. Penelitian ini adalah sebuah penelitian dengan menggunakan pendekatan kuantitatif dan termasuk penelitian ex-post facto. Subjek yang terlibat dalam penelitian ini adalah Guru Tahfidz di Pesantren Terpadu Darul Qur'an Mulia yang berjumlah 54 orang dengan cara simple random sampling. Instrumen penelitian yang dipakai adalah skala beban kerja dan skala stres kerja. Uji validitas menggunakan validitas isi yang dilakukan oleh profesional judgement. Hasil analisis butir yang dilakukan menunjukkan angka korelasi item total berkisar antara 0,278-0,579. Hasil uji reliabilitas stres kerja sebesar 0,84, dimensi beban waktu sebesar 0,767, dimensi beban upaya mental sebesar 0,743, dan dimensi beban tekanan psikologis 0,549. Berdasarkan hasil regresi linear berganda, ditemukan bahwa: (1) beban kerja, beban upaya mental, dan beban tekanan psikologis secara simultan (bersama-sama) berpengaruh terhadap stres kerja sebesar 0,375 atau $37,5 \%$. Sedangkan sisanya, yaitu $62,5 \%$ dijelaskan oleh variabel lain diluar model penelitian ini; (2) beban waktu tidak memiliki pengaruh positif terhadap stres kerja, dibuktikan berdasarkan nilai signifikansi 0,109;

(3) beban upaya mental berpengaruh positif terhadap stres kerja, dibuktikan berdasarkan nilai signifikansi 0,005, dengan nilai sumbangan efektif 20,8\%; (4) beban tekanan psikologis tidak memiliki pengaruh positif terhadap stres kerja, dibuktikan dengan nilai signifikansi 0,192.
\end{abstract}

Kata Kunci: beban kerja, stres kerja, guru

\begin{abstract}
This study aims to determine the effect of workload on workstress of tahfidz teacher in Darul Qur'an Mulia Boarding School. The workload is multidimensional, divided into 3 dimensions: time load, mental effort load, psychological stress load. So this study examines the effect of each dimension simultaneously or together on work stress on Tahfidz Teachers in Darul Qur'an Mulia Boarding School. This research used quantitative approach with ex-post facto research. The subject involve in this study were 54 tahfidz teachers of Darul Qur'an Mulia Boarding School with simple random sampling. Instruments used in this study were workload scale and workstress scale, validity test used content validity conducted by profesional judgement. The result of the item analysis showed that the total item correlation number ranged from 0,278 to 0,579 . The result for workstress's reliability test is $0,84,0,767$ for timeload, 0,743 for mental effort load, 0,549 for psychological stress load. Based on the results of the multiple linear regression, it was found that: (1) timeload, mental effort load, psychological stress load together had an effect on workstress as proved by 0,375 or $37,5 \% \mathrm{R}$ Square value. While the remaining $62,5 \%$ was explained by other variables outside this study; (2) timeload had no effect on workstress, as proved by 0,109 significance value; (3) mental effort load had an effect on workstress, as proved by 0,005 significance value, with an effective contribution value of $20,8 \%$; (4) psychological stress load had no effect on workstress, as proved by 0,192 significance value.
\end{abstract}

Keywords: workload, workstress, teacher

\section{Pendahuluan}

Dalam organisasi, sumber daya manusia (SDM) menjadi faktor utama dari keberhasilan organisasi. Salah satu masalah dari pengelolaan SDM yang tidak maksimal adalah dapat menimbulkan stres kerja. 
Seringkali SDM mengalami stres di tempat kerja yang diakibatkan oleh kondisi-kondisi di lingkungan kerja atau organisasi. Stres akan timbul jika individu dihadapkan dengan pemicu stres yang biasa disebut dengan "stressor". Setiap individu memiliki pemicu stres yang berbeda-beda. Dalam jurnalnya, Williams dan Cooper (dalam Cooper, 2013) berpendapat bahwa "stres di tempat kerja adalah hal yang umum dari kehidupan modern". Dalam konteks pekerjaan menurut Cooper (2013), yang dimaksud dengan stres kerja adalah faktor lingkungan yang negatif atau yang menjadi pemicu stres (misalnya kelebihan pekerjaan, konflik peran/ambiguitas, kondisi kerja yang buruk) yang terkait dengan pekerjaan tertentu. Setiap orang yang bekerja pernah mengalami hal tersebut. Namun sayangnya, tidak semua orang memiliki manajemen stres yang baik. Hal tersebut akan berdampak kepada produktivitas dari individu ataupun organisasi yang akan merugikan kedua belah pihak.

Stres kerja tergolong masalah serius yang masih sering dikeluhkan di berbagai sektor industri atau organisasi oleh para karyawan di berbagai belahan bumi. Di Eropa, permasalahan stres kerja menempati urutan ke-2 setelah gangguan muskuloskeletal (Petreanu, Iordache, \& Seracin, 2013). Selain itu, di kawasan Asia Pasifik tren stres kerja juga sudah melebihi rata-rata global yang berkisar 48\%. Berdasarkan hasil survey Regus (2012), dilaporkan bahwa tingkat stres di negara seperti Malaysia mencapai 57\%, Hongkong $62 \%$, Singapura 63\%, Vietnam $71 \%$, China 73\%, Indonesia 71\%, dan Thailand $75 \%$ (Habibi \& Jefri, 2018). Indonesia mengalami peningkatan sebesar $9 \%$ dari tahun lalu yang berada di tingkat 64\%. Tingginya persentase stres kerja di Indonesia tersebut selain dipengaruhi oleh faktor di dalam negeri juga terkait dengan faktor individu dan pekerjaan (Timah, 2014). Seperti yang diberitakan oleh Asep Candra lewat web Kompas pada bulan Juli 2011, dr. Dewi S Soemarko mengatakan bahwa "Harus disadari, 15-30\% pekerja pernah mengalami masalah kesehatan jiwa". Disebutkan juga pada berita tersebut bahwa pada 1990-an Fakultas Kedokteran Universitas Indonesia (FKUI) juga melakukan penelitian dengan hasil sekitar 30\% karyawan di Indonesia mengalami stres dengan beragam keluhan mulai dari ringan sampai berat.

Hasil wawancara dan observasi peneliti pada tanggal 10 Maret 2019 di pesantren menemukan bahwa banyak guru yang mengalami stress akibat beban kerja. Pesantren yang diobservasi adalah pesantren dengan visi dan misi yang berlandasan pada kitab suci Alquran, sehingga mayoritas dari kegiatan sehari-hari mereka selain belajar akademik adalah menghafal dan menyetorkan hafalan Alquran yang sudah mereka hafalkan. Dengan begitu, mereka memiliki guru yang biasa disebut dengan guru tahfidz untuk bertugas mendampingi santri/murid yang akan menyetorkan hafalan surat Alquran mereka. Subjek yang diambil adalah lima karyawan yang bekerja sebagai guru tahfidz/ pengajar pada bidang menghafal kitab Alquran. Tiga orang perempuan dan dua orang laki-laki, yang mana mereka masih mahasiswa dengan rata- rata usia 21 tahun dan juga melakukan pekerjaan sampingan dari pesantren.

Pada guru tahfidz di Pesantren Terpadu Darul Qur'an Mulia, lima subjek yang telah diwawancarai mengaku bahwa dirinya sering merasakan stres ketika harus menyelesaikan pekerjaan mereka. Stres tersebut sering terjadi ketika dipicu oleh kegiatan yang mengharuskan mereka mengerjakan pekerjaannya menjadi guru tahfidz dan melakukan pekerjaan tambahan secara bersamaan (misal: kuliah, tanggung jawab di yayasan, dan pekerjaan tambahan lainnya). Guru merasakan adanya tekanan ketika harus membuat laporan hasil belajar muridnya kepada atasan, selain itu mereka juga merasa mulai stres ketika mereka harus menghadapi anak- anak murid yang sulit diatur, begitu juga ketika mereka harus 
membuat surat rekomendasi ketika anak murid mereka hendak melanjutkan pendidikan ke luar negeri. Dari berbagai situasi tersebut, beberapa guru merasakan gejala fisik seperti cepat lelah, pusing, dan makan yang tidak teratur, bahkan dua dari lima sering jatuh sakit dan memilih untuk bolos dari mengajar.

Guru tahfidz di pesantren dikatakan memiliki jadwal yang sangat padat. Ketika bangun dari tidur melaksanakan sholat, guru tahfidz langsung melaksanakan tugasnya yaitu mendengarkan hafalan kitab Alquran dari muridnya hingga pagi tiba. Selanjutnya, mereka akan melaksanakan kuliah ataupun bekerja di yayasan pesantren tersebut. Kemudian kegiatan mengajar dilanjutkan setelah Sholat Asar dan Maghrib. Waktu menjelang tidur, mereka menyempatkan diri untuk menyelesaikan tugas kuliah ataupun tugas laporan yang belum mereka selesaikan untuk yayasan. Dengan demikian, guru tahfidz seringkali menghabiskan waktunya untuk pekerjaan.

Berdasarkan fenomena tersebut, terlihat bahwa faktor- faktor yang mempengaruhi stres kerja juga diliputi oleh beban kerja (Wagiu, Kolibu, \& Asrifuddin, 2017), umur, masa kerja, hubungan interpersonal, peran individu (Fitri, 2013), ketidakamanan kerja (Safaria, 2011), yang mana sangat terpampang jelas juga pengaruhnya pada produktifitas kerja karyawan itu sendiri (Petreanu, Iordache, \& Seracin, 2013). Berdasarkan faktor-faktor tersebut, terdapat juga hal yang penting bahwa kemampuan memanajemen stres di tempat kerja perlu dan sangat berguna untuk dimiliki karyawan (Dinata, 2018). Namun, ternyata karyawan itu sendiri tidak semua memiliki cara yang tepat untuk mengelola stres mereka dan lebih memilih untuk melupakannya lalu fokus pada kesulitan mereka untuk menyelesaikan tumpukan-tumpukan pekerjaan yang telah muncul sebagai pemicu stres mereka di tempat kerja. Hal tersebut juga akan menghasilkan dampak positif dan negatif kepada guru tahfidz.
Saat ini, sudah terlihat jelas bahwa terdapat dampak negatif pada fisik ataupun mental dari stres kerja yang dialami oleh subjek yang telah diwawancarai ketika survey. Dampak fisik yang sudah disampaikan pada saat observasi dan wawancara adalah adanya kelelahan fisik karena kurang tidur, maag, dan juga sering merasa pusing. Dampak mental yang mereka sampaikan berupa cemas menghadapi atasan, dan emosi buruk saat menghadapi murid yang tidak dapat diatur. Dampak negatif tersebut bisa menjadi dampak positif jika subjek melakukan refleksi/intropeksi untuk kualitas diri yang lebih baik, sehingga dapat menambah motivasi dalam bekerja. Bagi guru tahfidz, mereka memiliki hafalan al-qur'an yang harus mereka jaga dan harus diamalkan dalam kesehariannya. Mengingat hal tersebut diyakini bahwa dapat menjadi motivasi tambahan dalam diri individu untuk bekerja dan dapat mengurangi rasa beban pada pekerjaan mereka.

Namun, kenyataan di tempat observasi sedikit berbeda. Guru tahfidz yang menjadi subjek wawancara di sana telah mengeluhkan mengenai tumpukan pekerjaan yang harus diselesaikan dengan waktu yang tergolong mendesak bagi mereka, hal tersebut bersamaan dengan rasa lelah yang dirasakan. Adanya rasa tersebut dapat menjadi indikasi dari gejala adanya beban kerja pada karyawan sehingga belum dapat mengaktualisasikan dirinya dengan baik. Hal tersebut sesuai dengan pendapat Moray (Moray, 1979) yang mengatakan bahwa kompleksitas tugas, dinamika tugas, dan jumlah sub-tugas adalah sebagai aspekaspek dari timbulnya beban kerja pada karyawan. Beban kerja adalah variabel serius yang sangat mempengaruhi dunia pekerjaan. Dampak negatif yang disebabkan dari beban kerja itu sendiri juga sangat mempengaruhi karyawan dalam proses menyelesaikan pekerjaannya. Hal itu juga ditunjukkan pada kasus yang diberitakan oleh CNN Indonesia, ketua Dewan Perwakilan Rakyat (DPR) RI Bambang 
Soesatyo mengatakan beban kerja serta tekanan psikologis yang lahir akibat semua kontestan ingin menang memberi andil menjadi penyebab ratusan petugas Kelompok Penyelenggaraan Pemungutan Suara (KPPS) meninggal dunia di pemilihan umum 2019 lalu.

Selain itu, CNN Indonesia juga mengabarkan kasus lain yang memberikan gambaran serupa. Terdapat kabar bahwa dokter paru dengan inisial KY yang bertugas di rumah sakit swasta daerah Jakarta mengaku sangat stres dengan banyaknya pasien Covid-19 yang harus ditangani sehingga dirinya terpapar (positif) covid-19. Selain itu, terdapat beberapa pihak yang diketahui telah menyebarluaskan kabar bahwa dirinya meninggal dunia dan kabar tersebut membuat kondisinya semakin memburuk dan dirujuk ke rumah sakit yang lebih besar.

Berkaitan dengan beban kerja, ditemukan pada penelitian sebelumnya, beberapa perbedaan hubungan stres dengan faktor-faktor yang mempengaruhinya. Hal tersebut dapat dilihat pada hasil penelitian Wagiu (2017) yang mengatakan bahwa terdapat hubungan antara beban kerja dengan stres kerja pada perawat di ruang rawat inap Rumah Sakit Hermana Lembean. Selain itu, pada penelitian Putranto (2013) juga menyebutkan bahwa hasil penelitian menunjukkan persentase sebesar 30.60\% responden mendefinisikan stres kerja adalah kejenuhan kerja. Sebesar $33.61 \%$ responden menganggap faktor utama penyebab stres adalah karena beban pekerjaan. Kemudian, pada penelitian Haryanti (2013) juga memiliki hasil penelitian yang sama bahwa didapatkan beban kerja perawat sebagian besar adalah tinggi sehingga itu menghasilkan stres kerja pada karyawannya.

Namun, pada penelitian Fitri (2013), hasil penelitian menunjukkan bahwa tidak ada hubungan antara beban kerja mental dengan stres kerja. Dari penelitian ini dapat disimpulkan bahwa umur, masa kerja, hubungan interpersonal, dan peran individu dalam organisasi merupakan faktor-faktor yang berhubungan dengan stres kerja pada karyawan Bank BMT. Begitupula pada jurnal Habibi \& Jefri (2018) mengatakan bahwa beban kerja juga tidak berpengaruh terhadap stres kerja pada subjek penelitiannya. Dengan begitu, penelitian mereka menghasilkan kesimpulan yang berbeda dari jurnal-jurnal yang lainnya.

Dengan adanya perbedaan hasil penelitian dengan salah satu variable dari beberapa penelitian tersebut yaitu beban kerja, peneliti ingin menelitinya lebih lanjut dengan melihat permasalahan yang ada di lapangan. Peneliti melihat bahwa masalah stres kerja dan beban kerja di dalam organisasi menjadi gejala yang penting untuk diamati sejak adanya tuntutan pekerjaan yang efisien dan tuntutan yang lainnya di dalam pekerjaan. Jika individu merasakan tekanan atau stres dalam menyelesaikan pekerjaannya, maka itu akan sangat penting untuk diteliti karena berpengaruh pada hasil pekerjaannya dan menjadi tidak menguntungkan secara individu maupun organisasi. Hal tersebut menjelaskan betapa pentingnya penelitian ini untuk dilakukan karena stres kerja akan berpengaruh pada kinerja dan akan berkaitan dengan produktifitas pada individu maupun pada organisasi tersebut.

Dari permasalahan di atas, peneliti akan melaksanakan penelitian seputar stres kerja dan juga beban kerja pada subjek guru tahfidz di Pesantren Terpadu Darul Qur`an Mulia. Tujuan dari penelitian ini adalah untuk mengetahui apakah ada pengaruh beban kerja terhadap stres kerja pada guru tahfidz di Pesantren Terpadu Darul Qur'an Mulia.

Penelitian ini diharapkan dapat memberikan manfaat di bidang psikologi yaitu mengenai beban kerja dan stres kerja pada guru tahfidz di Pesantren Terpadu Darul Qur'an Mulia. Selain itu, penelitian ini diharapkan dapat memperkaya penelitian di bidang psikologi industri dan organisasi, sehingga hasil penelitian ini nantinya dapat dijadikan sebagai bahan penunjang 
penelitian lainnya yang berkaitan dengan beban kerja dan stres kerja. Serta dapat menjadi masukan dan informasi yang berkaitan dengan beban kerja dan stres kerja guru tahfidz.

\section{Metode Penelitian}

\section{Jenis penelitian}

Penelitian ini menggunakan pendekatan kuantitatif yang menekankan analisisisnya pada data angka yang dikumpulkan melalui prosedur pengukuran dan diolah dengan metode analisis statistik (Azwar, 2018). Pendekatan penelitian yang digunakan adalah ex post facto atau penelitian non eksperimen atau empirik. Penelitian ex post facto yaitu pendekatan pada subjek penelitian untuk meneliti yang sudah dimiliki oleh subjek penelitian secara wajar tanpa adanya usaha sengaja memberikan perlakuan untuk memunculkan variabel yang ingin diteliti (Dantes, 2012). Menurut Sappaile (2010) ex post facto juga merupakan sebuah penelitian yang bertujuan untuk meneliti atau mengetahui hubungan sebab-akibat yang tidak dimanipulasi atau tidak diberi perlakuan oleh peneliti. Dengan kata lain, adanya hubungan sebab-akibat tersebut didasarkan atas kajian teori yang menjelaskan bahwa munculnya suatu variabel disebabkan atau dilatarbelakangi oleh variabel tertentu

\section{Waktu dan tempat penelitian}

Penilitian dilakukan di Pesantren Terpadu Darul Qur'an Mulia, Gunungsindur, Bogor. Pesantren ini merupakan salah satu pesantren yang fokus dalam proses menghafal kitab suci Al-qur'an tanpa menurunkan peran akademik sekolah. Penelitian ini dimulai pada bulan januari 2020, pengambilan data pada bulan Maret, dan selesai ditulis Juni 2020.

\section{Subjek Penelitian}

Peneliti menggunakan rumus Slovin sehingga diperoleh data 54 orang dari 115 orang guru tahfidz. Adapun teknik pengambilan sampel yang digunakan adalah teknik simple random sampling.

\section{Teknik pengumpulan data dan instrumen}

Teknik pengumpulan data dalam penelitian ini menggunakan kuesioner. Skala yang digunakan dalam penelitian ini yaitu Instrumen GWSS untuk stres kerja dan SWAT untuk beban kerja. Skala stres kerja disusun berdasar dimensi dari General Work Stress Scale (GWSS) De Bruin (2006) yang membagi stress kerja menjadi 3 dimensi yang dirancang secara unidimensional, yaitu dimensi gangguan motivasi, gangguan kognitif, dan gangguan afektif. Skala ini telah dilakukan adaptasi bahasa.

Skala beban kerja dibuat berdasarkan dimensi dari skala Subjective Workload Assessment Scale (SWAT) yang dikembangkan Gary B. Reid dan Thomas E. Neygren. Skala ini memiliki konstrak multidimensional yang terdiri dari 3 dimensi, yaitu: beban waktu, beban usaha mental, dan beban tekanan psikologis. Subjective Workload Assessment Technique (SWAT) adalah rancangan multidimensi yang menggambarkan beban kerja mental dengan baik dan dimensi-dimensi tersebut akan sesuai dan relevan untuk dipakai pada penelitian ini. Instrumen berbentuk skala Likert. Skala stres kerja memiliki 9 item dan skala beban kerja memiliki 26 item, sehingga total item keseluruhan dalam penelitian ini adalah 35 item. Kedua skala tersebut memiliki item yang bersifat favorable dan unfavorable. 
Teknik Analisis data

Teknik analisis dalam penelitian ini menggunakan teknik analisis deskriptif. Selain iu menggunakan teknik uji analisis regresi linier berganda. Sebelum uji hipotesis dilakukan, penelitian melakukan uji prasyarat normalitas dan linearitas. Uji hipotesis dengan regresi linear berganda dilakukan untuk mengetahui seberapa besar pengaruh variabel bebas atau independen, yaitu $\mathrm{X} 1, \mathrm{X} 2$, dan $\mathrm{X} 3$ terhadap variabel dependen, yaitu $\mathrm{Y}$.

\section{Hasil Penelitian dan Pembahasan}

\section{Karakteristik subjek}

Data hasil penelitian ini diperoleh melalui penyebaran skala stres kerja dan beban kerja kepada guru tahfidz di Pesantren Terpadu Darul Qur'an Mulia. Subjek yang terlibat dalam penelitian ini sebanyak 54 orang dengan 23 laki-laki dan 31 perempuan.

\section{Hasil data deskriptif}

Skor stres kerja dikategori dengan menggunakan rerata 20,593 dan standar deviasi 6,172. Kategorisasi dari dari stres kerja dapat dilihat pada tabel 1.

Tabel 1. Kategorisasi stress kerja dan dimensi beban waktu

\begin{tabular}{lcc}
\hline Kategori & $\begin{array}{c}\text { Stress } \\
\text { kerja }\end{array}$ & $\begin{array}{c}\text { Dimensi } \\
\text { beban waktu }\end{array}$ \\
\hline Sangat Tinggi & 7 & 3 \\
Tinggi & 8 & 16 \\
Sedang & 21 & 20 \\
Rendah & 16 & 10 \\
Sangat Rendah & 2 & 5 \\
\hline Total & $\mathbf{5 4}$ & $\mathbf{5 4}$ \\
\hline
\end{tabular}

Berdasarkan tabel, sebagian besar subjek yaitu 21 orang (39\%) memiliki stress kerja di level sedang, Adapun subjek dengan dimensi beban waktu level sedang sebanyak 20 orang atau setara dengan 37\% dari total subjek.
Tabel 2. Kategorisasi dimensi beban upaya mental dan beban tekanan psikologis

\begin{tabular}{lcc}
\hline Kategori & $\begin{array}{c}\text { Dimensi } \\
\text { beban } \\
\text { upaya } \\
\text { mental }\end{array}$ & $\begin{array}{c}\text { Dimensi } \\
\text { beban } \\
\text { tekanan } \\
\text { psikologis }\end{array}$ \\
\hline Sangat Tinggi & 5 & 4 \\
Tinggi & 11 & 11 \\
Sedang & 20 & 23 \\
Rendah & 14 & 11 \\
Sangat Rendah & 4 & 5 \\
\hline Total & $\mathbf{5 4}$ & $\mathbf{5 4}$ \\
\hline
\end{tabular}

Sebagian besar subjek memiliki dimensi beban upaya mental pada kategori sedang yaitu sebanyak 20 orang (37\%). Adapun pada dimensi beban tekanan psikologis, sebagian besar yaitu sejumlah 23 orang $(43 \%)$ berada di level sedang.

\section{Hasil uji prasyarat}

Berdasarkan uji normalitas dengan Kolmogorov-Smirnov, didapat nilai Z sebesar 0,815 dengan signifikansi $>0,05$. Dengan demikian disimpulkan bahwa sebaran data penelitian berdistribusi normal. Syarat normalitas terpenuhi.

Adapun uji linieritas dilakukan antara stress kerja dengan masing-masing dimensi beban kerja. Hasil uji linieritas nantara stress kerja dengan dimensi beban waktu ditemukan sebesar 0,101 dengan signifikansi<0,05. Hasil uji linieritas antara stress kerja dan dimensi beban upaya mental ditemukan sebesar 0,749 dengan signifikansi $<0,05$. Adapun hasil uji linieritas antara stress kerja dan beban tekanan psikologis sebesar 0,194 dengan signifikansi<0,05. Dengan demikian disimpulkan bahwa terdapat hubungan linier antar variabel yang diteliti.

\section{Hasil uji regresi}

Uji hipotesis dilakukan untuk mengetahui ada tidaknya pengaruh variabel 
independen (beban waktu, beban upaya mental, beban tekanan psikologis) terhadap variabel dependen (stres kerja). Uji hipotesis dalam penelitian ini menggunakan analisis regresi linear berganda dengan bantuan SPSS versi 25.0. Berdasarkan uji ANOVA atau uji $\mathrm{F}$, didapatkan nilai $\mathrm{F}$ hitung sebesar 10,015 dengan nilai Signifikansi 0,000. Dengan demikian diketahui bahwa beban waktu (X1), beban upaya mental (X2), dan beban tekanan psikologis (X3) secara simultan (bersama-sama) berpengaruh terhadap stres kerja $(\mathrm{Y})$. Dengan demikian, maka persyaratan agar kita dapat memaknai nilai koefisien determinasi dalam analisis regresi linear berganda sudah terpenuhi.

Didapat nilai koefisien determinasi (R Square) adalah sebesar 0,375. Besarnya angka koefisien determinasi (R Square) adalah 0,375 atau sama dengan 37,5\%. Angka tersebut mengandung arti bahwa beban kerja (X1), beban upaya mental (X2), beban tekanan psikologis (X3) secara simultan (bersama-sama) berpengaruh terhadap stres kerja $(\mathrm{Y})$ sebesar 37,5\%. Hal tersebut menunjukkan bahwa hipotesis mayor pada penelitian ini diterima.

Berdasarkan uji parsial, ditemukan tidak ada pengaruh beban waktu (X1) terhadap stress kerja $(\mathrm{Y})$ dan sumbangan efektif kecil yaitu hanya 8,5\%. Selain itu, juga tidak ada pengaruh secara parsial dimensi beban tekanan psikologis (X3) pada stress kerja $(\mathrm{Y})$ dan sumbangan efektif kecil yaitu $8,2 \%$. Hal ini ditunjukkan dengna nilai signifikansi $>0,05$. Dari uji parsial hanya dimensi beban upaya mental (X2) yang secara signifikan berkorelasi parsial dengan sumbangan efektif sebesar 20,8\%.

\section{Pembahasan}

Berdasarkan hasil analisis deskriptif, diketahui bahwa rata-rata tingkat stres kerja guru tahfidz berada pada kategori sedang. Rata-rata dimensi beban waktu pada guru tahfidz ada di kategori sedang. Berdasarkan hasil studi kasus dan observasi sebelumnya, diketahui bahwa waktu yang tersedia lebih sedikit dari waktu yang dibutuhkan. Dengan demikin, menurut Reid \& Nygren (1988) timbulnya beban kerja adalah terjadinya tumpang tindihnya tugas.

Pada dimensi beban upaya mental rata- rata guru tahfidz berada di kategori sedang. Menurut Reid \& Nygren (1988) Dimensi ini juga cenderung mencakup konsep kapasitas mental, dimana kapasitas mental seseorang akan sangat subjektif. Hal ini bisa mencakup tuntutan yang terkait dengan berbagai tingkat tugas telah dimanipulasi oleh hal-hal seperti fungsi pemaksaan, penalaran induktif, penalaran deduktif, atau pengambilan memori. Ketika studi kasus sebelumnya, hal tersebut diketahui sering terjadi antara guru tahfidz dengan atasan ataupun orangtua ketika menyampaikan pencapaian murid. Pada dimensi beban tekanan psikologis, rata-rata guru tahfidz berada di kategori sedang. Menurut Reid \& Nygren (1988) dimensi ini dapat diwakili oleh pemicu stres spesifik seperti ketakutan akan kerusakan fisik, ketakutan akan kegagalan, ketegangan, ketidakbiasaan, dan disorientasi.

Berdasarkan hasil uji regresi linear berganda, diketahui bahwa dimensi beban waktu, dimensi beban upaya mental, dan dimensi beban tekanan psikologis secara simultan (bersama-sama) berpengaruh terhadap stres kerja sebesar 37,5\%. Dengan demikian, diketahui kesimpulan bahwa terdapat pengaruh beban kerja terhadap stres kerja pada guru tahfidz, dengan arti lain hipotesis mayor diterima. Pada hipotesis minor terdapat tiga hipotesis dari terdapat pengaruh antara 3 dimensi variabel beban kerja terhadap stres kerja guru tahfidz di Pesantren Terpadu Darul Qur'an Mulia.

Dari hasil uji regresi linear berganda, walaupun ketiga dimensi tersebut secara bersama-sama memiliki pengaruh terhadap 
variabel dependen, dalam uji $t$ yang dilakukan, didapatkan hasil bahwa secara parsial hanya beban upaya mental yang positif mempengaruhi stres kerja pada guru tahfidz di Pesantren Terpadu Darul Qur'an Mulia. Nilai koefisien regresi dimensi beban upaya mental secara parsial memberikan sumbangan efektif pengaruh positif sebesar 20,8\% terhadap stres kerja. Pengaruh positif itu bermakna semakin tinggi beban upaya mental, maka semakin tinggi pula tingkat stres kerjanya.

Jika dilihat juga berdasarkan hasil uji hipotesis, skor stres kerja itu dapat meningkat bersamaan dengan meningkatnya beban kerja. Seperti menurut Reid \& Nygren (1988) yang mendefinisikan beban kerja sebagai tugas-tugas mental pada individu yang mampu diskala kuantitatifkan secara subyektif, maka dihasilkan pula persamaan garis regresi dari penelitian ini. Stres kerja pada guru tahfidz di pesantren terpadu Darul Qur'an Mulia diteliti menunjukkan nilai positif. Artinya, bahwa semakin tinggi dimensi beban waktu pada guru tahfidz, maka stres kerjanya akan naik sebesar 0,298. Dengan arti lain, jika beban waktu (X1) meningkat 1 satuan, maka stres kerja akan meningkat sebesar 0,298. Selain dimensi beban waktu, ada juga dimensi beban upaya mental. jika beban upaya mental (X2) meningkat 1 satuan, maka stres kerja akan meningkat sebesar 0,639. Dimensi ketiga terdapat beban tekanan psikologis yang hasilnya jika beban tekanan psikologis (X3) meningkat 1 satuan, maka stres kerja akan meningkat sebesar 0,598.

Sangat kecilnya pengaruh beban waktu dan beban tekanan psikologis dapat ditinjau dari budaya dan iklim yang ada, perbedaan pribadi, dan suasana hati yang dirasakan guru tahfidz pada tempat pengambilan data yakni Pesantren Terpadu Darul Qur'an Mulia. Guru tahfidz memang mengutarakan terdapat stres kerja yang tinggi dikarenakan beban kerja yang tinggi pula. Namun, dengan iklim dan suasana kedekatan mereka dengan kitab suci Alquran membuat mereka merasa memiliki obat penawar untuk stres yang mereka alami. Dengan kata lain, stres kerja mereka dapat menurun juga karena dapat pengaruh dari suasana hati yang dirasakan dan iklim dari pesantren tersebut.

Walaupun hipotesis minor pertama dan hipotesis minor ketiga pada penelitian ini ditolak, dan hanya hipotesis minor kedua yang diterima, hasil uji koefisien determinasi (R Square) secara simultan (bersama-sama) pada penelitian ini berpengaruh terhadap stres kerja sebesar 37,5\%. Hal tersebut membuktikan bahwa kedua hipotesis yang ditolak masih memberikan pengaruh terhadap stres kerja, dikarenakan dimensi dari variabel beban kerja saling membantu dan berkaitan untuk melihat pengaruh 3 dimensi tersebut apakah dapat mempengaruhi stres kerja. Nilai sisanya $62,5 \%$ dapat dipengaruhi variabel lain yang tidak diteliti, seperti hasil penelitian Habibi dan Jefri (2018) yang menyebutkan bahwa variabel independen seperti jenis kelamin, jadwal kerja, konflik peran, serta konflik interpersonal yang mempengaruhi stres kerja

\section{Simpulan dan saran}

Simpulan

Berdasarkan hasil keseluruhan yang peneliti dapat dalam penelitian ini, disimpulkan:

1. Terdapat pengaruh positif secara simultan antara variabel beban kerja dengan stres kerja pada guru tahfidz di Pesantren Terpadu Darul Qur'an Mulia.

2. Tidak ada pengaruh beban waktu terhadap stres kerja guru tahfidz pesantren terpadu Darul Qur'an Mulia.

3. Ada pengaruh dimensi beban upaya mental terhadap stres kerja guru tahfidz pesantren terpadu Darul Qur'an Mulia.

4. Tidak ada pengaruh beban tekanan psikologis terhadap stres kerja guru 
tahfidz pesantren terpadu Darul Qur'an Mulia.

Saran

Berdasarkan hasil penelitian, terdapat beberapa saran.

1. Bagi pihak pesantren, perlu meninjau secara bersama-sama antara stres kerja dengan beban kerja guru tahfidz agar tidak mengganggu produktifitas kinerja. Dengan begitu, meningkatkan fokus pesantren terhadap kesejahteraan guru tahfidz secara individual dalam dunia pekerjaan juga dapat lebih didahulukan sebelum fokus dengan target- target pesantren agar semua terpenuhi.

2. Bagi peneliti selanjutnya, dapat mengaplikasikan variabel independen lain untuk melihat bagaimana pengaruhnya dengan variabel stres kerja, karena dalam penelitian ini besarnya pengaruh yang didapat tidak terlalu tinggi dan terdapat dua dimensi dari beban kerja yang diteliti tidak memiliki pengaruh atau dengan pengaruh sangat kecil terhadap stres kerja. Selain itu, peneliti selanjutnya diharapkan dapat meminimalisir bias yang terjadi karena kurangnya interaksi dengan karyawan yang akan diteliti, dengan salah satu cara memberikan angket dikala jam istirahat. Cakupan generalisasi yang luas juga dapat dilakukan karena mampu menjawab permasalahan untuk semua guru.

\section{Daftar Pustaka}

Azwar, S. (2018). Metode Penelitian Psikologi Edisi III. Yogyakarta: Pustaka Pelajar.

Candra, A. (2011). 30 persen pekerja kantor alami stres. Diambil kembali dari Kompas.com:https://amp.kompas. com/kupan $\mathrm{g} / \mathrm{read} / 2011 / 07 / 20 / 10232458 / 30$. persen.peker ja.kantor.alami.stres
Cooper, C. L. (2013). From Stress To WellBeing Volume 1. UK: The Palgrave Macmillan.

Dantes,N. (2012). Metode Penelitian. Yogyakarta: CV Andi Offset.

De Bruin, G. P. (2006). The Dimensionality Of The General Work Stress Scale A Hierarchical Exploratory Factor Analysis. SA Journal Of Industrial Psychology, 32 (4), 68-75.

De Bruin, G. P., \& Taylor, N. (2006). The Job Demand-Control Model of Job Strain Across Gender, SA Journal Of Industrial Psychology, 32 (1), 6673.

Dinata, K. I. (2018). Pengaruh Pelatihan Manajemen Stres Terhadap Motivasi Kerja Karyawan PT. CI. Thesis, Universitas Mercu Buana, Yogyakarta.

Elizabeth, J. (2017). Stres Kerja Ditinjau Dari Beban Kerja Pada Dokter Di Rumah Sakit. Skripsi, Universitas Gadjah Mada.

Fitri, A. M. (2013). Analisis Faktor-Faktor Yang Berhubungan Dengan Kejadian Stres Kerja Pada Karyawan Bank (Studi pada Karyawan Bank BMT). Jurnal Kesehatan Masyarakat, Volume 2, Nomor 1.

Habibi, \& Jefri. (2018). Analisis Faktor Risiko Stres Kerja Pada Pekerja Di Unit Produksi PT. Borneo Melintang Buana Export. Journal of Nursing and Public Health, 50-59.

Hakim, D. D., \& Agustina, I. (2019). Hubungan Antara Beban Kerja Dengan Stres Kerja Pada Fotographer Di Yogyakarta. Skripsi, Universitas Islam Indonesia.

Haryanti, Aini, F., \& Purwaningsih, P. (2013). Hubungan Antara Beban Kerja Dengan Stres Kerja Perawat Di Instalasi Gawat Darurat RSUD 
Kabupaten Semarang. Jurnal Managemen Keperawatan, 1(1), 4856.

Moray, N. (1979). Mental Workload: Its Theory And Measurement. New York: Springer Science+Business Media, LCC.

Petreanu, V., Iordache, R., \& Seracin, M. (2013). The National Research and Development Institute for Occupational Safety and Health. Assessment of Work Stress Influence on Work Productivity in Romanian Companies. Procedia Social and Behavioral Sciences 92, 420-425.

Putranto, C. (2013). Faktor-Faktor Yang Mempengaruhi Stres Kerja: Studi Indegenous Pada Guru Bersuku Jawa. Journal of Social and Industrial Psychology 2, 12-17.

Putri, K. U. (2020, April Sabtu). Cerita Dokter Terinfeksi Corona hingga Digosipkan Meninggal. Diambil kembali dari $\mathrm{CNN}$ INDONESIA:https://m.cnnindon esia.com/na sional/20200403173134-20490147/cerita- dokter-terinfeksicorona-hingga-digosipkanmeninggal

Reid, G. B., \& Nygren, T. E. (1988). Subjective Workload Assessment Technique: A Scaling Procedure For Measuring Mental Workload. In P.A Hancock \& N. Meshkati (Eds.) Advences in Psychology. 52 . Human Mental Workload., 185-218.

Safaria, T. (2011). Peran Religious Coping Sebagai Moderator Dari Job Insecurity Terhadap Stres Kerja Staf Akademik. Jurnal Psikologi Universitas Ahmad Dahlan Yogyakarta, 8(2), 156-170.
Sappaile, B. I. (2010). Konsep Penelitian Ex-Post Facto. Jurnal Pendidikan Matematika , 105- 113.

Timah, N. E. (2014). Analizing The Influence Of Job Stress On Employee Productivity At PT. Bank Tabungan Negara (PERSERO) Manado. Jurnal EMBA. Faculty Of Economic And Business, International Business Administration (ABA), Program University Of Sam Ratulangi Manado, 1759- 1767.

Wagiu, C. F., Kolibu, F. K., \& Asrifuddin, A. (2017). Hubungan Beban Kerja Dengan Stres Kerja Pada Perawat Di Ruang Rawat Inap Rumah Sakit Hermana Lembean. Skripsi. Fakultas Kesehatan Masyarakat Universitas Sam Ratulangi, 1-8 